\title{
Phenotypic and Genotypic Diversity of Multidrug-Resistant Pseudomonas aeruginosa Isolates from Bloodstream Infections Recovered in the Hospitals of Belo Horizonte, Brazil
}

\author{
Hanoch S.M. Inacio ${ }^{a}$ Maria Rosa Q. Bomfim ${ }^{c}$ Rafaela O. França ${ }^{a}$ \\ Luiz M. Farias $^{a}$ Maria Auxiliadora R. Carvalho ${ }^{a}$ José Carlos Serufo ${ }^{b}$ \\ Simone Gonçalves Santos ${ }^{\text {a }}$ \\ a'Departamento de Microbiologia, Instituto de Ciências Biológicas, and ${ }^{\text {b}}$ Faculdade de Medicina, Universidade \\ Federal de Minas Gerais, Belo Horizonte, and ${ }^{\mathrm{C} C}$ entro Universitário do Maranhão, São Luís, Brazil
}

\section{Key Words \\ Pseudomonas aeruginosa $\cdot$ Resistance markers - Genetic diversity $\cdot$ Bloodstream infections}

\begin{abstract}
Background: Pseudomonas aeruginosa commonly causes nosocomial bloodstream infections and the emergence of a variety of $\beta$-lactamases (BLs) is worrying. In 5 hospitals in Belo Horizonte, Brazil, the presence of phenotypes encoding $\mathrm{BL}$ genes was established and the genetic diversity of the $P$. aeruginosa strains recovered from bloodstream infections was analyzed. Materials and Methods: The isolates were investigated using a disk diffusion (DD) method and the Etest ${ }^{\circledR}$, for encoding metallo- $\beta$-lactamases (MBLs), oxacillinases and cephalosporinases. Genes and genetic diversity were evaluated by random amplified polymorphic DNA (RAPD) genotyping and enterobacterial repetitive intergenic consensus (ERIC)-PCR. Results: Twelve strains (30\%) were positive for MBLs by Etest and DD, 15 were cephalosporinase-positive and $87.5 \%$ were positive for $b / a_{\mathrm{SPM}-1}$ and $b / a_{\mathrm{VIM}-1}$. Twentythree strains (57.5\%) were grouped into profile A, 32.5\% into profile $B$ and $10 \%$ into profile $C$ by RAPD genotyping. ERIC-
\end{abstract}

PCR revealed a varying degree of similarity between strains, ranging from 45 to $100 \%$. Conclusions: The results suggest distinct clonal populations in the 5 hospitals studied, indicating a potentially problematic epidemiological situation in Belo Horizonte, Brazil.

(c) 2014 S. Karger AG, Basel

\section{Introduction}

Pseudomonas aeruginosa is one of the major agents recovered from patients with nosocomial bloodstream infections. Its relevance is highlighted by the severity of these infections, its increasing drug resistance, the high costs of treatment and high morbidity [1].

The frequent use of antibiotics has contributed to the emergence of drug resistance and the production of a variety of $\beta$-lactamases (BLs) amongst $P$. aeruginosa strains, an important resistance mechanism observed in many bacteria [2]. Recently, multidrug resistance was defined as acquired nonsusceptibility to at least one agent in three or more antimicrobial categories [3]. The resistance of bacterial strains to several classes of antibiotics seriously

\section{KARGER}

E-Mail karger@karger.com

www.karger.com/che (c) 2014 S. Karger AG, Basel

0009-3157/14/0601-0054\$39.50/0
Simone Gonçalves dos Santos

Departamento de Microbiologia

Instituto de Ciências Biológicas, Universidade Federal de Minas Gerais

Avenida Antônio Carlos 6627, Pampulha, Belo Horizonte 31.270-901 (Brazil)

E-Mail simonegsantos@icb.ufmg.br 
compromises the treatment of infected patients. In contrast to community-acquired strains, isolates from hospital environments exhibit high rates of antimicrobial resistance and are often resistant to multiple drugs [4]. P. aeruginosa bacteremia, in particular, is associated with high mortality. Reported mortality rates exceed $50 \%$ in some series and are even higher within certain populations, such as in patients with severe underlying comorbid conditions or those with immunosuppression [5].

$P$. aeruginosa populations undergo frequent recombination events contributing to the evolution of successful epidemic clones [6]. These populations are dominated by common clones that can be isolated from diverse clinical and environmental sources [7]. Thus, in order to genotype and differentiate between the isolates and clonal groups of $P$. aeruginosa, several molecular typing schemes have been proposed [8]. In this context, the establishing of accurate genetic similarity between individual genotypes is an essential and decisive point for clustering and analyzing inter- and intrapopulation diversity. The objective of this study was to evaluate the antimicrobial resistance and production of metallo- $\beta$-lactamase (MBL), oxacillinase and cephalosporinase enzymes, and the genetic diversity of strains of $P$. aeruginosa isolated from patients with bloodstream infections.

\section{Material and Methods}

\section{Bacterial Identification and Drug Susceptibility Testing}

Forty multidrug-resistant $P$. aeruginosa strains isolated from blood cultures between December 2008 and June 2009 were evaluated. All samples were previously identified using the GN card of the bioMerieux VITEK $2^{\circledR}$ system. The strains were obtained from 5 hospitals that provide general assistance (clinical, surgical and hematological) and emergency services in the city of Belo Horizonte, Minas Gerais, Brazil.

Phenotypic screening for drug susceptibility was performed by the disk diffusion (DD) method, and minimum inhibitory concentration (MIC) determination by agar dilution (AD) with the following antimicrobials: $30 \mu \mathrm{g}$ ceftazidime (CAZ), $30 \mu \mathrm{g}$ cefepime (FEP), $30 \mu \mathrm{g}$ amikacin (AMK), $10 \mu \mathrm{g}$ gentamicin (GEN), $5 \mu \mathrm{g}$ ciprofloxacin (CIP), $5 \mu \mathrm{g}$ levofloxacin (LVX), $30 \mu \mathrm{g}$ aztreonam (ATM), $10 \mu \mathrm{g}$ imipenem (IMP), 100/10 $\mu$ g piperacillin/tazobactam (TZP), $10 \mu \mathrm{g}$ meropenem (MEM) and $300 \mu \mathrm{g}$ polymyxin B (PB). All records were obtained from Laborclin (São Paulo, Brazil). Results were interpreted according to the cut-off points recommended by the Clinical and Laboratory Standards Institute [9].

Phenotypic Detection of Class B (MBL) and Class C

(Cephalosporinase) Enzymes Related to Resistance

To study MBLs, two different phenotyping methods were used: the DD method and the MBL Etest. DD was used to evaluate cephalosporinases.

Multidrug-Resistant $P$. aeruginosa Isolates from Bloodstream Infections
$M B L$ Evaluation

DD Method. This was performed with some modifications, as described below $[10,11]$. The MBL inhibitors used in this study were 2-mercaptopropionic acid (MPA), 2-mercaptoacetic acid (MAA) and ethylenediaminetetraacetic acid (EDTA) (Sigma, St. Louis, Mo., USA) at concentrations of $2.11,4.14$ and $100 \mathrm{mM}$, respectively. The substrates used were disks containing $30 \mu \mathrm{g} \mathrm{CAZ}$ and $10 \mu \mathrm{g}$ IMP (Laborclin, Pinhais, Brazil). Strains that exhibited antimicrobial synergism between CAZ and/or and at least one of the employed inhibitors were considered to be MBL-producing strains. MBL-producing samples displayed MBL distortion and a broadened zone of inhibition of bacterial growth in the region of diffusion of the MBL inhibitor. In negative tests, the zone of inhibition of bacterial growth was unchanged.

Etest ${ }^{\circledR}$. Strips containing a gradient of IMP ranging from 4 to $256 \mu \mathrm{g} / \mathrm{ml}$ at one end and from 1 to $64 \mu \mathrm{g} / \mathrm{ml}$ of IMP associated with EDTA at the other end, were added to plates inoculated with the bacterial suspension and then incubated at $35^{\circ} \mathrm{C}$ for $24 \mathrm{~h}$. A sample was considered to be MBL-producing when the ratio of the MIC $(\mu \mathrm{g} / \mathrm{ml})$ for IMP to the MIC for IMP plus EDTA was $\geq 8$ and when there was a decrease of 3 dilutions between IMP and IMP plus EDTA. The onset of deformation of the ellipse (i.e. the appearance of a ghost area) was also considered indicative of the production of MBLs and extended-spectrum BLs.

\section{Cephalosporinase Evaluation}

DD Method. This was performed with some modifications, as described below [9-11]. The bacterial suspension was prepared in saline for turbidity corresponding to point 0.5 on the McFarland scale, and this was inoculated with the aid of a swab on a $15-\mathrm{cm}$ plate with agar Muller-Hinton medium (Becton-Dickinson ${ }^{\circledR}$, Le Pont de Blaix, France). A disk containing $30 \mu \mathrm{g}$ cefoxitin and $30 \mu \mathrm{g}$ CAZ (substrate) was placed with another disk containing $30 \mu \mathrm{g}$ ATM (inductor) at a distance of $2 \mathrm{~cm}$. The appearance of a zone of 'truncated' junction between the 2 disks was considered presumptive for the presence of the extended-spectrum BL C Ambler class.

\section{Genotypic Detection of BLs by PCR}

Bacterial DNA was extracted by thermal lysis followed by centrifugation at $4^{\circ} \mathrm{C}$ for $30 \mathrm{~s}$ at $9,000 \mathrm{rpm}[2,7,10]$. The DNA content of the supernatant was quantified by Nanodrop ${ }^{\circledR}$. Each reaction was performed in a final volume of $25 \mu \mathrm{l}$ with $12.5 \mu$ l Master Mix (Promega Corp., Madison, Wis., USA) $1.5 \mu$ l of primers (table 1) and $100 \mathrm{ng}$ bacterial DNA plus nuclease-free water. PCR amplification was performed as previously described [8] to detect the following genes: $b l a_{\mathrm{SPM}-1}, b l a_{\mathrm{IMP}-1}, b l a_{\mathrm{GIM}-1}$ and $b l a_{\mathrm{VIM}-1}$. For $b l a_{\mathrm{SIM}-1}$ and $b l a_{\mathrm{AmpC}}$, the cycling conditions were as described by other authors $[12,13]$, respectively. For the $b l a_{\mathrm{OXA} 23}, b l a_{\mathrm{OXA} 24}, b l a_{\mathrm{OXA} 51}$ and $b l a_{\text {OXA58 }}$ genes, PCR amplification was performed according to the literature [14].

\section{Enterobacterial Repetitive Intergenic Consensus PCR}

Enterobacterial repetitive intergenic consensus (ERIC)-PCR was used to rapidly type $P$. aeruginosa strains carrying the bla $a_{\mathrm{SPM}-1}$ gene ( 35 strains). The ERIC1 (5'-ATGTAAGCTCCTGGGGATTCAC-3') and ERIC2 (5-'AAGTAAGTGACTGGGGTGAGCG-3') primers previously described were used $[10,15]$. ERIC-PCR amplifications were performed with $100 \mathrm{ng}$ of genomic bacterial DNA plus $12.5 \mu$ l of Master Mix (Promega Corp.), $1.5 \mu$ l of each primer and ultrapure water to bring the final reaction volume to $25 \mu$ l. The 
Table 1. Primers and expected product sizes used for detecting genotypic BLs

\begin{tabular}{|c|c|c|c|}
\hline Gene & Primer sequence $\left(5^{\prime}-3^{\prime}\right)$ & $\begin{array}{l}\text { Expected product } \\
\text { size, bp }\end{array}$ & $\begin{array}{l}\text { Reference } \\
\text { No. }\end{array}$ \\
\hline$b l a_{\mathrm{SPM}-1}$ & $\begin{array}{l}\text { AAAATCTGGGTACGCAAACG } \\
\text { ACATTATCCGCTGGAACAGG }\end{array}$ & 271 & [7] \\
\hline$b l a_{\mathrm{IMP}-1}$ & $\begin{array}{l}\text { GAATAGAGTGGCTTAACTCTC } \\
\text { AGATAACCTAGTGGTTTGG }\end{array}$ & 189 & \\
\hline$b l a_{\mathrm{VIM}-1}$ & $\begin{array}{l}\text { CGAATGCGCAGCACCAG } \\
\text { CTGGTGCTGCGCATTCG }\end{array}$ & 390 & \\
\hline$b l a_{\mathrm{GIM}-1}$ & $\begin{array}{l}\text { TCGACACACCTTGGTCTGAA } \\
\text { AACTTCCAACTTTGCCATGC }\end{array}$ & 477 & \\
\hline$b l a_{\mathrm{SIM}-1}$ & $\begin{array}{l}\text { TACAAGGGATTCGGCATCG } \\
\text { TAATGGCCTGTTCCCATGTG }\end{array}$ & 571 & {$[8]$} \\
\hline$b l a_{\mathrm{AmpC}}$ & $\begin{array}{l}\text { CAGTAGCGAGACTGCGCA } \\
\text { ATAACCACCCAGTCACGC }\end{array}$ & 631 & {$[9,13]$} \\
\hline$b l a_{\mathrm{Oxa} 23}$ & $\begin{array}{l}\text { GATCGGATTGGAGAACCAGA } \\
\text { ATTTCTGACCGCATTTCCAT }\end{array}$ & 501 & {$[14]$} \\
\hline$b l a_{\mathrm{Oxa} 24}$ & $\begin{array}{l}\text { GGTTAGTTGGCCCCCTTAAA } \\
\text { AGTTGAGCGAAAAGGGGATT }\end{array}$ & 246 & \\
\hline$b l a_{\mathrm{Oxa} 51}$ & $\begin{array}{l}\text { TAATGCTTTGATCGGCCTTG } \\
\text { ATTTCTGACCGCATTTCCAT }\end{array}$ & 353 & \\
\hline$b l a_{\mathrm{Oxa} 58}$ & $\begin{array}{l}\text { AAGTATTGGGGCTTGTGCTG } \\
\text { CCCCTCTGCGCTCTACATAC }\end{array}$ & 599 & \\
\hline
\end{tabular}

PCR conditions included an initial denaturation at $95^{\circ} \mathrm{C}$ for $2 \mathrm{~min}$ followed by 30 cycles of $90^{\circ} \mathrm{C}$ for $30 \mathrm{~s}, 52^{\circ} \mathrm{C}$ for $1 \mathrm{~min}$ and $72^{\circ} \mathrm{C}$ for $1 \mathrm{~min}$, with a final extension at $65^{\circ} \mathrm{C}$ for $8 \mathrm{~min}[10,15]$.

All PCR-amplified products were resolved by electrophoresis on a $2 \%(\mathrm{w} / \mathrm{v})$ agarose gel in Tris-acetate-EDTA buffer. The samples were run for approximately $120 \mathrm{~min}$ at $90 \mathrm{~V}$. The specific products were observed after ethidium bromide staining using a standard ultraviolet-light transilluminator $[10,15,16]$.

\section{Random Amplified Polymorphic DNA Genotyping}

The DNA of the all 40 strains of $P$. aeruginosa was subjected to random amplified polymorphic DNA (RAPD) genotyping with primers detecting CagA2, 5' -ATT TAG AAG CAG GCT TTA GC$3^{\prime}$ and CMVin $2,5^{\prime}$-GGT AGC AC GCG GGT TTC GAC-3', which produce an average of 7-10 distinct PCR profiles per strain [17].

Gene amplification was performed with an initial cycle of $94^{\circ} \mathrm{C}$ for $2 \mathrm{~min}$, followed by 5 cycles of denaturation at $94^{\circ} \mathrm{C}$ for $30 \mathrm{~s}$, annealing at $30^{\circ} \mathrm{C}$ for $5 \mathrm{~min}$ and extension at $72^{\circ} \mathrm{C}$ for $1 \mathrm{~min}$. This was then followed by 25 cycles of denaturation at $94^{\circ} \mathrm{C}$ for $30 \mathrm{~s}$, annealing at $30^{\circ} \mathrm{C}$ for $1 \mathrm{~min}$, extension at $72^{\circ} \mathrm{C}$ for $1 \mathrm{~min}$ and final extension at $72^{\circ} \mathrm{C}$ for $7 \mathrm{~min}$ [17]. RAPD profiles were resolved by electrophoresis in a buffer ( 2 mM EDTA, $10 \mathrm{mM}$ Trisborate, $\mathrm{pH} 8.0$ ) on a $6 \%$ polyacrylamide gel. The gel was silverstained, visualized, photographed and analyzed, as described previously [18].

\section{Quality Control}

$P$. aeruginosa strains producing the enzymes of interest based on the phenotypic test were sequenced; after the presence of the corresponding gene had been confirmed, they were used as posi- tive controls. As negative controls for all phenotypic tests, the reference strains $P$. aeruginosa ATCC 27853 and Escherichia coli ATCC 25922 were used.

Ethical Aspects

This study was approved by the Research Ethics Committees of the participating hospitals and the COEP/UFMG (ETIC 614/08).

\section{Data Analysis}

The bands for each strain, primer and PCR method were scored as absent (0) or present (1) in order to construct a genotype dendrogram. To visualize hierarchical relationships among the sample profiles, the patterns generated by RAPD genotyping or ERICPCR were interpreted using numerical taxonomy and multivariate analysis (NTSYS v2.1, Exeter Software, New York, N.Y., USA). RAPD and ERIC-PCR dendrograms were constructed with the unweighted pair group method with arithmetic mean (UPGMA) using Dice's similarity coefficient.

\section{Results}

\section{Antimicrobial Susceptibility Profiles}

In this study, antimicrobial susceptibility testing of $P$. aeruginosa strains with the DD method and determination of MIC with the AD method showed high rates of resistance to all tested drugs. With the DD method, it was observed that $70-90 \%$ of the isolates were resistant to CAZ,
Inacio/Bomfim/França/Farias/Carvalho/ Serufo/Santos 
Fig. 1. Resistance profiles of 40 P. aeruginosa strains isolated from blood cultures from patients at 5 hospitals in this study (by DD).

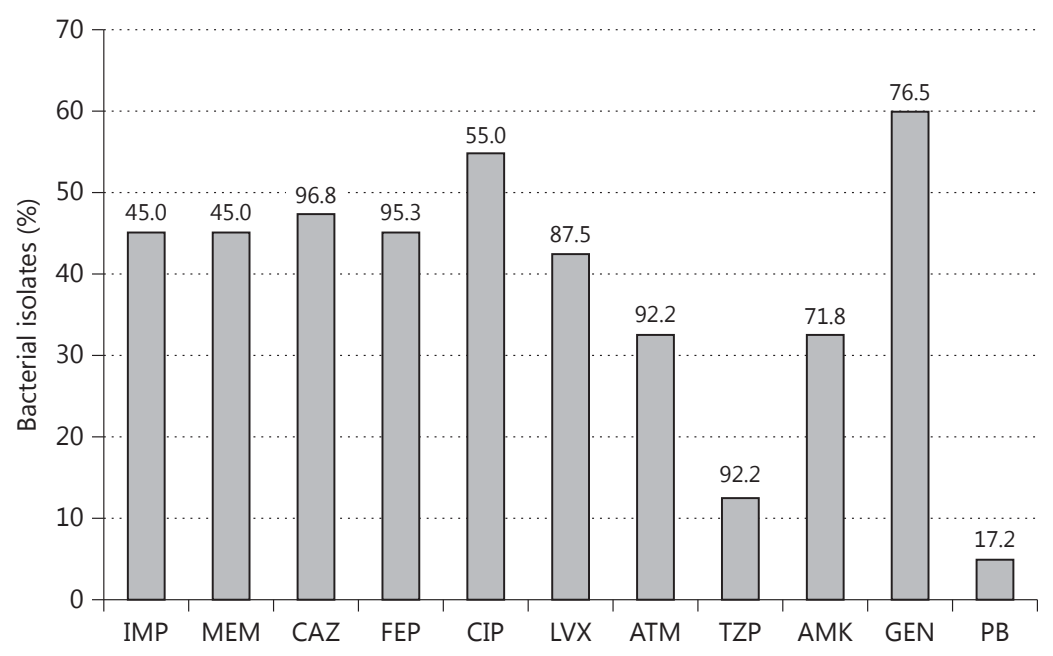

Table 2. $\mathrm{MIC}_{50}$ and $\mathrm{MIC}_{90}$ of $P$. aeruginosa multiresistant strains $(\mathrm{n}=40)$ isolated from blood cultures in 5 hospitals in Belo Horizonte

\begin{tabular}{|c|c|c|c|c|c|}
\hline \multirow{3}{*}{$\begin{array}{l}\text { Anti- } \\
\text { microbials }\end{array}$} & \multicolumn{5}{|c|}{ P. aeruginosa } \\
\hline & \multicolumn{3}{|c|}{ breakpoints } & \multicolumn{2}{|c|}{$\mathrm{MIC}, \mu \mathrm{g} / \mathrm{ml}$} \\
\hline & $\mathrm{S}$ & I & $\mathrm{R}$ & $\mathrm{MIC}_{50}$ & $\mathrm{MIC}_{90}$ \\
\hline IMP & $\leq 4$ & 16 & $\geq 32$ & 4 & 64 \\
\hline MEM & $\leq 8$ & 16 & $\geq 32$ & 2 & 16 \\
\hline CAZ & $\leq 8$ & 16 & $\geq 32$ & 8 & 256 \\
\hline FEP & $\leq 8$ & 16 & $\geq 32$ & 8 & 128 \\
\hline CIP & $\leq 1$ & 2 & $\geq 4$ & 0.125 & 64 \\
\hline LVX & $\leq 2$ & 4 & $\geq 8$ & 1 & 32 \\
\hline ATM & $\leq 8$ & 16 & $\geq 32$ & 4 & 16 \\
\hline $\mathrm{TZP}$ & $\leq 64 / 4$ & - & $\geq 128 / 4$ & 16 & 64 \\
\hline AMK & $\leq 16$ & 32 & $\geq 64$ & 4 & 64 \\
\hline GEN & $\leq 4$ & 8 & $\geq 16$ & 32 & 512 \\
\hline $\mathrm{PB}$ & $\leq 2$ & 4 & $\geq 8$ & 0.25 & 0.5 \\
\hline
\end{tabular}

MIC $_{90}=$ MIC capable of inhibiting the growth of $90 \%$ of the bacterial strains; MIC $_{50}=$ MIC capable of inhibiting the growth of $50 \%$ of the bacterial strains.

FEP, LVX, ATM, TZP, AMK and GEN and that $45.0 \%$ were resistant to IMP and MEM (fig. 1). Similar results were found with the $\mathrm{AD}$ method, with the $\mathrm{MIC}_{90}$ (i.e. the MIC capable of inhibiting the growth of $90 \%$ of the bacterial strains) higher than the breakpoint for all antimicrobials tested and the $\mathrm{MIC}_{50}$ higher for most of them (table 2).

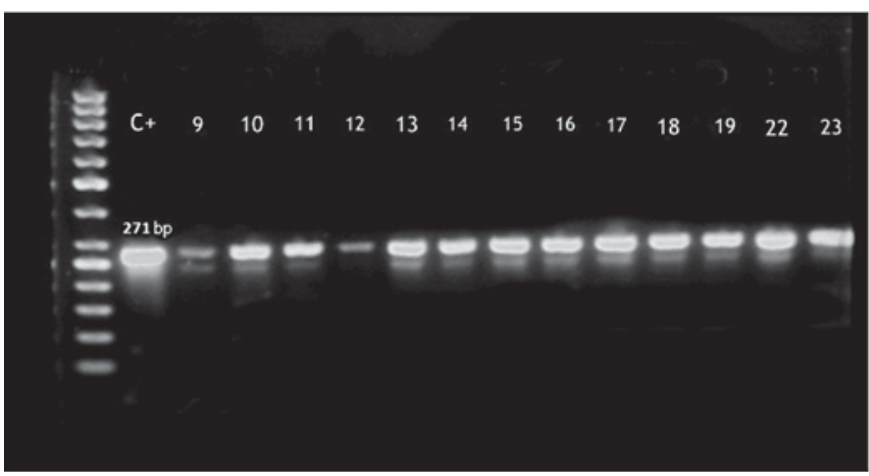

Fig. 2. Detection of bla $a_{\mathrm{SPM}-1}$ gene $(271 \mathrm{bp})$ in $P$. aeruginosa isolates 9-19, 22 and 23. C+ = positive control. Molecular pattern: $50 \mathrm{bp}$.

\section{Phenotypic Detection of BLs}

Twelve (30\%) P. aeruginosa strains were found to be positive for MBL with the Etest and DD methods. The percentage of positive samples ranged from 12.5 to $29.6 \%$, according to each hospital. Regarding the DD method, the evaluated strains demonstrated synergy with at least one substrate and inhibitor. The CAZ + MPA, CAZ + MAA and CAZ + EDTA combinations were positive in $27.5 \%(11 / 40)$ of the strains and other combinations were positive in only $2.5 \%$ (table 3 ).

In the cephalosporinase (AmpC) phenotypic study, 15 (37.5\%) $P$. aeruginosa strains were positive according to the DD method. 


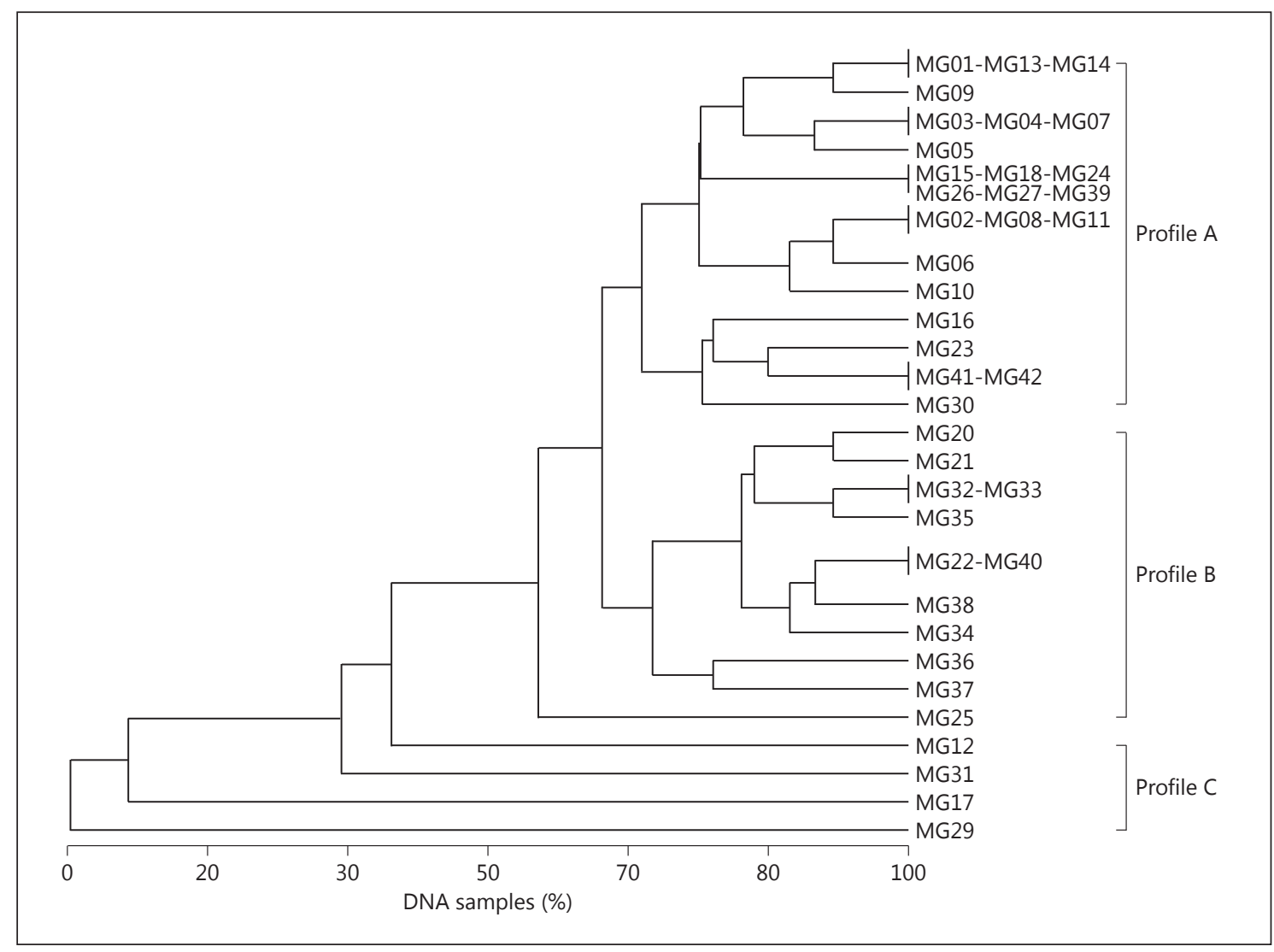

Fig. 3. Dendrogram based on Dice's coefficient of similarity using the UPGMA method implemented by the NTSYS program, showing the relationships between 40 samples of $P$. aeruginosa isolated from hospitals A-E, and amplified by RAPD.

\section{Genotypic Detection of BLs}

Among the 40 strains of $P$. aeruginosa, 35 (87.5\%) had PCR products corresponding to $b l a_{\mathrm{SPM}-1}$ and $b l a_{\mathrm{VIM}-1}$ gene fragments, and 35 (87.5\%) of the amplified products were consistent with $b l a_{\mathrm{SPM}-1}$ (fig. 2). The simultaneous occurrence of the bla $a_{\mathrm{SPM}-1}$ and $b l a_{\mathrm{VIM}-1}$ genes was observed in 6 strains of $P$. aeruginosa (15\%). Genes bla IMP-1 $_{\mathrm{IM}}$, $b l a_{\mathrm{SIM}-1}, b l a_{\mathrm{GIM}-1}, \quad b l a_{\mathrm{OXA} 23}, b l a_{\mathrm{OXA} 24}, b l a_{\mathrm{OXA} 58}$, and $b l a_{\mathrm{AmpC}}$ were not identified in any of the evaluated strains.

\section{RAPD Genotyping}

A dendrogram was constructed using RAPD data from 40 isolates. The hierarchical cluster analysis discriminated the genotypes of $P$. aeruginosa into 3 distinct profiles (AC). Of the 40 DNA samples amplified, 23 (57.5\%) were grouped into profile A, 13 (32.5\%) into profile B and 4 (10\%) into profile C (fig. 3 ). Table 4 shows the results of the RAPD genotyping of strains carrying the MBL genes and their respective units in the different profiles.
Table 3. Frequency of inhibitor-substrate combinations by phenotypic (DD method) for detection of MBLs in P. aeruginosa strains $(\mathrm{n}=40)$

\begin{tabular}{lcr}
\hline $\begin{array}{l}\text { Antimicrobial agent } \\
+ \text { inhibitor }\end{array}$ & $\begin{array}{l}\text { Number of } \\
\text { positive samples }\end{array}$ & $\%$ \\
\hline IMP + MPA & 1 & 2.5 \\
IMP + MAA & 1 & 2.5 \\
IMP + EDTA & 1 & 2.5 \\
CAZ + MPA & 11 & 27.5 \\
CAZ + MAA & 11 & 27.5 \\
CAZ + EDTA & 11 & 27.5 \\
\hline
\end{tabular}

\section{Enterobacterial Repetitive Intergenic Consensus}

Genetic fingerprinting with ERIC primers produced consistent banding patterns for $35 P$. aeruginosa strains carrying the $b l_{S P M-1}$ gene, showing an average of 7-10 fragments per $P$. aeruginosa sample. These data generated
Inacio/Bomfim/França/Farias/Carvalho/ Serufo/Santos 
Table 4. RAPD genotyping profile of $P$. aeruginosa strains carrying genes for MBLs according to the hospital unit where patients were treated

\begin{tabular}{|c|c|c|c|c|}
\hline Isolate & Hospital & Unit & Profile & Gene \\
\hline 1 & \multirow[t]{3}{*}{ A } & ICU & A & $b l a_{\mathrm{SPM}-1}$ \\
\hline 2 & & ICU & A & - \\
\hline 3 & & ICU & A & - \\
\hline 4 & \multirow[t]{9}{*}{$\mathrm{C}$} & ICU & $\mathrm{A}$ & $b l a_{\mathrm{SPM}-1}$ \\
\hline 5 & & ICU & A & $b l a_{\mathrm{SPM}-1}$ \\
\hline 6 & & ONCO & A & $b l a_{\mathrm{SPM}-1}$ \\
\hline 7 & & ICU & A & $b l a_{\mathrm{SPM}-1}$ \\
\hline 8 & & ICU & A & $b l a_{\mathrm{SPM}-1 / \mathrm{VIM}-1}$ \\
\hline 9 & & ICU & A & $b l a_{\mathrm{SPM}-1}$ \\
\hline 10 & & $\mathrm{ICU}$ & A & $b l a_{\text {SPM-1/VIM-1 }}$ \\
\hline 11 & & CLI & A & $b l a_{\mathrm{SPM}-1}$ \\
\hline 12 & & CLI & $\mathrm{C}$ & $b l a_{\mathrm{SPM}-1}$ \\
\hline 13 & \multirow[t]{4}{*}{ B } & EXT & A & $b l a_{\mathrm{SPM}-1}$ \\
\hline 14 & & ICU & A & $b l a_{\mathrm{SPM}-1}$ \\
\hline 15 & & CLI & A & $b l a_{\mathrm{SPM}-1}$ \\
\hline 16 & & CLI & A & $b l a_{\mathrm{SPM}-1 / \mathrm{VIM}-1}$ \\
\hline 17 & \multirow[t]{7}{*}{$\mathrm{D}$} & CLI & $\mathrm{C}$ & $b l a_{\mathrm{SPM}-1}$ \\
\hline 18 & & CLI & A & $b l a_{\mathrm{SPM}-1}$ \\
\hline 19 & & CLI & B & $b l a_{\mathrm{SPM}-1}$ \\
\hline 20 & & CLI & B & - \\
\hline 21 & & CLI & B & - \\
\hline 22 & & CLI & $\mathrm{B}$ & $b l a_{\mathrm{SPM}-1}$ \\
\hline 23 & & CLI & A & - \\
\hline 24 & \multirow[t]{17}{*}{$\mathrm{E}$} & ICU & A & $b l a_{\mathrm{SPM}-1}$ \\
\hline 25 & & ICU & B & $b l a_{\mathrm{SPM}-1}$ \\
\hline 26 & & ICU & A & $b l a_{\mathrm{SPM}-1 / \mathrm{VIM}-1}$ \\
\hline 27 & & CLI & A & $b l a_{\mathrm{SPM}-1}$ \\
\hline 28 & & BTU & B & $b l a_{\mathrm{SPM}-1}$ \\
\hline 29 & & BTU & $\mathrm{C}$ & $b l a_{\mathrm{SPM}-1 / \mathrm{VIM}-1}$ \\
\hline 30 & & CLI & A & $b l a_{\mathrm{SPM}-1}$ \\
\hline 31 & & CLI & $\mathrm{C}$ & $b l a_{\mathrm{SPM}-1}$ \\
\hline 32 & & ICU & B & $b l a_{\mathrm{SPM}-1}$ \\
\hline 33 & & BTU & B & $b l a_{\mathrm{SPM}-1}$ \\
\hline 34 & & ICU & B & $b l a_{\text {SPM-1/VIM-1 }}$ \\
\hline 35 & & CLI & B & $b l a_{\mathrm{SPM}-1}$ \\
\hline 36 & & ICU & $\mathrm{B}$ & $b l a_{\mathrm{SPM}-1}$ \\
\hline 37 & & BTU & B & $b l a_{\mathrm{SPM}-1}$ \\
\hline 38 & & CLI & B & $b l a_{\mathrm{SPM}-1}$ \\
\hline 39 & & $\mathrm{ICU}$ & A & $b l a_{\mathrm{SPM}-1}$ \\
\hline 40 & & BTU & A & $b l a_{\mathrm{SPM}-1}$ \\
\hline
\end{tabular}

$\mathrm{BTU}=$ Burn therapy unit; $\mathrm{CLI}=$ clinical unit; $\mathrm{ONCO}=$ oncology unit.

the matrix for the construction of the dendrogram from all samples. One high level of genetic diversity among the isolates was observed, demonstrating no genetic correlation between them (fig. 4).

Multidrug-Resistant $P$. aeruginosa Isolates from Bloodstream Infections

\section{Discussion}

The increased use of carbapenems in hospitalized patients contributes to an increased selective pressure on nosocomial microorganisms, which favors the selection of bacterial subpopulations with reduced sensitivity or resistance to these antimicrobial agents. Bacterial strains of $P$. aeruginosa resistant to most antimicrobials and sensitive only to PB have been isolated by clinical microbiology laboratories in most Brazilian hospitals [19, 20]; this was corroborated by the results presented in this study. In a study over a period of 1 year in Mexico, $P$. aeruginosa was the third most frequently isolated species from blood in an intensive care unit (ICU) and the predominant isolate in central venous catheters among the species included in the ESKAPE group of multidrug-resistant microorganisms [21].

The production of MBL enzymes by some pathogen types is of concern worldwide. These enzymes are notable for their broad spectrum of activity against most $\beta$-lactam agents, including carbapenems, and also their resistance to BL inhibitors [22]. MBLs hydrolyze all the $\beta$-lactam drugs that are commercially available, with the monobactams, e.g. ATM, being the only exception $[2,22,23]$. ATM shows antimicrobial activity in vitro against $P$. aeruginosa strains, with a sensitivity rate of $67.5 \%$. This profile is consistent with the production of MBLs by these strains because ATM is not hydrolyzed by these enzymes. However, the results of our study showed that $32.5 \%$ of $P$. aeruginosa strains were resistant to ATM; this suggests a possible association with other resistance mechanisms, or even the production of BLs.

$P$. aeruginosa-producing MBLs are often resistant to all treatment options, so drugs such as $\mathrm{PB}$ are frequently the therapeutic choice, despite their toxicity $[22,24]$. In our study, $5 \%(2 / 40)$ of $P$. aeruginosa strains were intermediately resistant to $\mathrm{PB}$, and the $\mathrm{MIC}_{50}$ and $\mathrm{MIC}_{90}$ for this antimicrobial were 0.25 and $0.5 \mathrm{mg} / \mathrm{ml}$, respectively.

In the phenotypic MBL research, a higher number of producing samples was observed when EDTA was used as inducer. It is known that EDTA may increase bacterial cell wall permeability and that zinc (chelated by EDTA) accelerates decomposition and IMP decreases OprD expression of $P$. aeruginosa [25].

In this study, due to the higher sensitivity and specificity of PCR, we used this methodology for the detection of MBLs, but the phenotypic expression levels of MBL genes were not assessed. The differences observed here between the phenotypic and genotypic methods of detection of 
Fig. 4. Dendrogram based on Dice's coefficient of similarity using the UPGMA method implemented by the NTSYS program, showing the relationships between 35 samples of $P$. aeruginosa isolated from hospitals A-E, and amplified by ERICPCR.

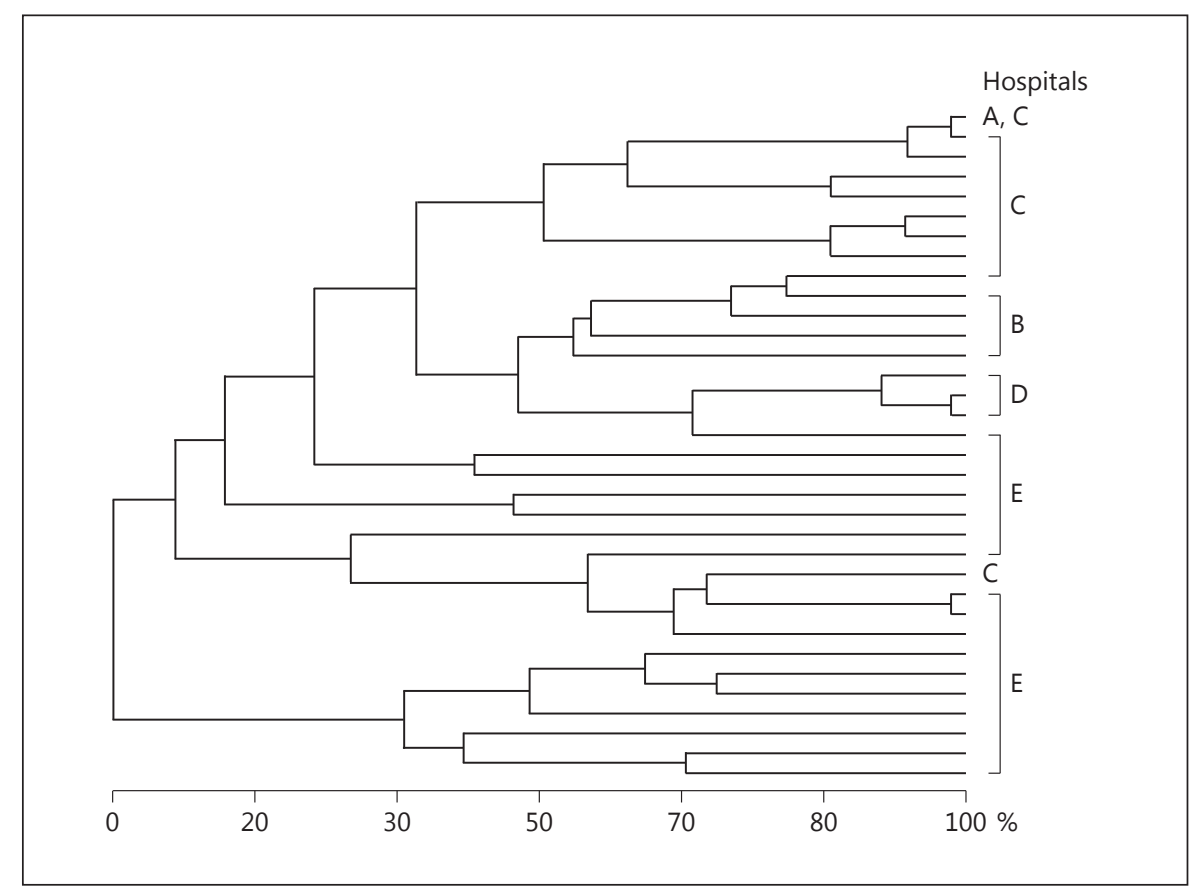

MBLs may be because MBL producers might act as silent reservoirs of such resistance determinants [26].

Different DNA typing methods have been frequently used to investigate the diversity of antibiotic resistance genes and the epidemiological distribution of $P$. aeruginosa [8-27]. In this study, PCR assays were used to evaluate the presence of carbapenem-hydrolyzing class $\mathrm{D} B \mathrm{BL}$ and MBL genes, while ERIC-PCR and RAPD genotyping were performed to identify and establish the relatedness between the isolates. PCR is an appropriate method for the detection of different reference genes encoding BLs [8-16, 27]. Brazil, which has a significant continental land mass and is the largest country in Latin America, is characterized by wide variations in geography and economy. By means of PCR assays, several MBL genes in P. aeruginosa have been detected in different regions of Brazil. One study in Uberlândia, Minas Gerais, detected the bla $a_{\mathrm{SPM}-1}$ gene in $33 \%(3 / 15)$ of the samples [28] while in Passo Fundo, Rio Grande do Sul, this gene was detected in $77.6 \%(173 / 223)$ [20] of the samples. In São Paulo, São Paulo, another 2 studies detected the gene $b l a_{\mathrm{SPM}-1}$; the first was detected in $17.2 \%(n=5 / 25)$ [29] of the isolates, and the second reported $b l a_{\mathrm{SPM}-1}$ in $81 \%$ and $b l a_{\mathrm{VIM}-2}$ in $19 \%$ of the isolates [30]. In our study, the genotypic detection of BLs showed that $87.5 \%$ (35/40) of P. aeruginosa samples carried the bla $a_{\mathrm{SPM}-1}$ gene and $15 \%(6 / 40)$ carried the $b l a_{\mathrm{VIM}-1}$ gene.
Using RAPD genotyping to evaluate 40 P. aeruginosa strains, it was possible to identify 3 different genetic profiles: 23 (57.5\%) strains with profile A, 13 (32.5\%) strains with profile B and 4 (10\%) strains with profile C. According to the data generated by the similarity analysis, strain MG1 (from the ICU of hospital A) and strains MG13 and MG14 (from the ICU of hospital C) showed the same profile bands (fragments of 150, 165, 195, 280 and $330 \mathrm{bp}$ ), with a similarity of approximately $85 \%$. The same similarity was observed for fragments of 165, 195, 280, 330 and $450 \mathrm{bp}$ for samples MG2, MG11 and MG8 from hospital B.

As shown in the dendrogram, Dice's coefficient measures suggest that there is a clonal population with the same lineage of resistance genes from different sectors in the same hospital as well across institutions. It is noteworthy that all these strains carried the $b l a_{\mathrm{SPM}-1}$ gene and the strain MG8 carryied the $b l a_{\mathrm{SPM}-1}$ and $b l_{\mathrm{VIM}-1}$ genes simultaneously.

\section{Conclusions}

With the DD method and MIC determination, we evaluated bacterial resistance to antimicrobials and revealed high rates of antimicrobial resistance among $P$. $a e$ ruginosa strains. Even resistance to $\mathrm{PB}$, which is considered quite effective against the bacteria studied, was ob-
60

Chemotherapy 2014;60:54-62 DOI: $10.1159 / 000365726$
Inacio/Bomfim/França/Farias/Carvalho/ Serufo/Santos 
served. Genes encoding MBL (i.e. $b l a_{\mathrm{VIM}}$ and $b l a_{\mathrm{SPM}}$ ) have been identified in almost all $P$. aeruginosa strains evaluated, while those responsible for the production of oxacilinases $\left(b l a_{\text {OXA23 }}, b l a_{\text {OXA24 }}, b l a_{\text {OXA51 }}\right.$ and $\left.b l a_{\text {OXA58 }}\right)$ were identified only in some of them. Finally, our results suggest that certain clonal populations are circulating among representative strains in the different hospitals evaluated, demonstrating a worrying epidemiological situation in the city of Belo Horizonte. Further studies with a larger number of strains would be required to confirm and obtain a better characterization of the panorama of resistance in the hospitals studied. Healthcare professionals must be alert and follow standard and/or specific precautions to avoid dissemination inside each hospital and between different hospitals.

\section{Acknowledgments}

This work was supported by the Conselho Nacional de Desenvolvimento Científico e Tecnológico (CNPq), Fundação de Amparo à Pesquisa do Estado de Minas Gerais (FAPEMIG), the Fundação de Amparo à Pesquisa e Desenvolvimento Científico do Maranhão (FAPEMA) and the Coordenação de Aperfeiçoamento de Pessoal de Nível Superior (CAPES). The authors thank the laboratory personnel from the participating hospitals as well as Luzia Rosa and Jose Sérgio Rezende de Souza Barros (AT/CNPq) from the Federal University of Minas Gerais for their technical support.

\section{Disclosure Statement}

There are no conflicts of interest.

\section{References}

1 Zilberberg MD, Shorr AF: Prevalence of multidrug-resistant Pseudomonas aeruginosa and carbapenem-resistant enterobacteriaceae among specimens from hospitalized patients with pneumonia and bloodstream infections in the United States from 2000 to 2009. J Hosp Med 2013;8:559-563.

-2 Walsh TR, Toleman MA, Hryniewicz W, Bennett PM, Jones RN: Evolution of an integron carrying blaVIM-2 in Eastern Europe: report from the SENTRY Antimicrobial Surveillance Program. J Antimicrob Chemother 2003;52:116-119.

-3 Magiorakos AP, Srinivasan A, Carey RB, Carmeli Y, Falagas ME, Giske CG, Harbarth S, Hindler JF, Kahlmeter G, Olsson-Liljequist B, Paterson DL, Rice LB,Stelling J, Struelens MJ, Vatopoulos A, Weber JT, Monnet DL: Multidrug-resistant, extensively drug-resistant and pandrug-resistant bacteria: an international expert proposal for interim standard definitions for acquired resistance. Clin Microbiol Infect 2012;18:268-281.

4 Queenan AM, Bush K: Carbapenemases: the versatile beta-lactamases. Clin Microbiol Rev 2007;20:440-458.

5 Bowers DR, Liew YX, Lye DC, Kwa AL, Hsu LY, Tam VH: Outcomes of appropriate empiric combination versus monotherapy for Pseudomonas aeruginosa bacteremia. Antimicrob Agents Chemother 2013;57;12701274.

6 Hammami S, Boutiba-Ben Boubaker I, Ghozzi R, Saidani M, Amine S, Ben Redjeb S: Nosocomial outbreak of imipenem-resistant Pseudomonas aeruginosa producing VIM-2 metallo-beta-lactamase in a kidney transplantation unit. Diagn Pathol 2011;6:106.
7 Yan JJ, Hsueh PR, Ko WC, Luh KT, Tsai SH, Wu HM, Wu JJ: Metallo-beta-lactamases in clinical Pseudomonas isolates in Taiwan and identification of VIM-3, a novel variant of the VIM-2 enzyme. Antimicrob Agents Chemother 2001;45:2224-2228.

8 Speijer H, Savelkoul PHM, Bonten MJ, Stobberingh EE, Tjhie JHT: Application of different genotyping methods for Pseudomonas aeruginosa in a setting of endemicity in an intensive care unit. J Clin Microbiol 1999;37: 3654-3661.

9 Clinical and Laboratory Standards Institute: Performance standards for antimicrobial susceptibility testing, 17th informational supplement, 2011.

10 Martins HS, Bomfim MRQ, França RO, Farias LM, Carvalho MAR, Serufo JC, Santos SG: Resistance markers and genetic diversity in Acinetobacter baumannii strains recovered from nosocomial bloodstream infections. Int J Environ Res Public Health 2014;11:14651478.

11 Dalmarco EM, Blatt SL, Córdova CMM: Identificação laboratorial de $\beta$-lactamases de espectro estendido (ESBLs). Ver Bras Anal Clin 2006;38:171-177.

-12 Lee K, Yum JH, Yong D, Lee HM, Kim HD, Docquier JD, Rossolini GM, Chong Y: Novel acquired metallo-beta-lactamase gene, bla(SIM-1), in a class 1 integron from Acinetobacter baumannii clinical isolates from Korea. Antimicrob Agents Chemother 2005; 49:4485-4491.

13 Coudron PE, Moland ES, Thomson KS: Occurrence and detection of AmpC beta-lactamases among Escherichia coli, Klebsiella pneumoniae, and Proteus mirabilis isolates at a veterans medical center. J Clin Microbiol 2000;38:1791-1796.
14 Woodford N, Ellington MJ, Coelho JM, Turton JF, Ward ME, Brown S, Amyes SGB, Livermore DM: Multiplex PCR for genes encoding prevalent OXA carbapenemases in Acinetobacter spp. Int J Antimicrob Ag 2006; 27:351-353.

15 Silbert S, Pfaller MA, Hollis RJ, Barth AL, Sader HS: Evaluation of three molecular typing techniques for nonfermentative Gram-negative bacilli. Infect Control Hosp Epidemiol 2004;25:847-851.

16 Versalovic J, Koeuth T, Lupski JR: Distribution of repetitive DNA sequences in eubacteria and application to fingerprinting of bacterial genomes. Nucleic Acids Res 1991;19: 6823-6831.

17 Dabrowski W, Czekajlo-Kolodziej U, Medrala D, Giedrys-Kalemba S: Optimisation of AP-PCR fingerprinting discriminatory power for clinical isolates of Pseudomonas aeruginosa. FEMS Microbiol Lett 2003;218:51-57.

18 Sanguinetti CJ, Dias Neto E, Simpson AJG: Rapid silver staining and recovery of PCR products separated on polyacrylamide gels. Biotech 1994;17:915-918.

19 Ribeiro J, Mendes RE, Domingos R, Franca E, Silbert S, Jones RN, Sader HS: Microbiological and epidemiological characterization of imipenem-resistant Pseudomonas aeruginosa strains from a Brazilian tertiary hospital: report from the SENTRY Antimicrobial Surveillance Program. J Chemother 2006;18: 461-467.

20 Machado GM, Lago A, Fuentefria SR, Fuentefria DB: Occurrence and the susceptibility to antimicrobial agents in Pseudomonas aeruginosa and Acinetobacter sp. at a tertiary hospital in southern Brazil. Rev Soc Bras Med Trop 2011;44:168-172. 
21 Llaca-Díaz JM, Mendonza-Olazarán S, Camacho-Ortiz A, Flores S, Garza-González E: One-year surveillance of ESKAPE pathogens in an intensive care unit in Monterrey, Mexico. Chemotherapy 2012;58:475-481.

22 Cornaglia G, Giamarellou H, Rossolini GM: Metallo-beta-lactamases: a last frontier for beta-lactams? Lancet Infect Dis 2011;11:381393.

23 Livermore DM: Multiple mechanisms of antimicrobial resistance in Pseudomonas aeruginosa: our worst nightmare? Clin Infect Dis 2002;34:634-640.

24 Falagas ME, Rafailidis PI, Matthaiou DK: Resistance to polymyxins: Mechanisms, frequency and treatment options. Drug Resist Updat 2010;13:132-138.
$25 \mathrm{Qu}$ T, Zhang J, Wang J,Tao J,Yu Y, Chen Y, Zhou J, Li L: Evaluation of phenotypic tests for detection of metallo- $\beta$-lactamase-producing Pseudomonas aeruginosa strains in China. J Clin Microbiol 2009;47:1136-1142.

26 Picão RC, Carrara-Marroni FE, Gales AC, Venâncio EJ, Xavier DE, Tognim MC, Pelavo JS: Metallo- $\beta$-lactamase-production in meropenem susceptible Pseudomonas aerugino$s a$ isolates: risk for silent spread. Mem Inst Oswaldo Cruz 2012;107:747-751.

27 Speert DP: Molecular epidemiology of Pseudomonas aeruginosa. Front Biosci 2002;1 354-361.

28 Cezario RC, Duarte De Morais L, Ferreira JC, Costa-Pinto RM, da Costa Darini AL, Gontijo-Filho PP: Nosocomial outbreak by imipe- nem-resistant metallo-beta-lactamase-producing Pseudomonas aeruginosa in an adult intensive care unit in a Brazilian teaching hospital. Enferm Infecc Microbiol Clin 2009;27: 269-274.

29 Toleman MA, Simm AM, Murphy TA, Gales AC, Biedenbach DJ, Jones RN, Walsh TR: Molecular characterization of SPM-1, a novel metallo-beta-lactamase isolated in Latin America: report from the SENTRY antimicrobial surveillance programme. J Antimicrob Chemother 2002;50:673-679.

30 Franco MR, Caiaffa-Filho HH, Burattini MN, Rossi F: Metallo-beta-lactamases among imipenem-resistant Pseudomonas aeruginosa in a Brazilian university hospital. Clinics 2010; 65:825-829. 